\title{
Mammary cell activity and turnover in dairy cows treated with the prolactin-release inhibitor quinagolide and milked once daily
}

\author{
M. Boutinaud, ${ }^{\star} \dagger^{1}$ V. Lollivier, ${ }^{*} \dagger \neq$ L. Finot, ${ }^{\dagger} \dagger$ R. M. Bruckmaier,§ and P. Lacasse\# \\ *INRA, UMR1080, Production du lait, F-35000 Rennes, France \\ †Agrocampus Ouest, UMR1080, Production du lait, F-35000 Rennes, France \\ fUniversité européenne de Bretagne, F-35000 Rennes, France \\ §Veterinary Physiology, Vetsuisse Faculty, University of Bern, CH- 3012 Switzerland \\ \#Dairy and Swine Research and Development Centre, Agriculture and Agri-Food Canada, 200 College St., Sherbrooke, Quebec, \\ Canada J1M 0C8
}

\begin{abstract}
To assess the regulation of mammary cell activity, survival, and proliferation by prolactin (PRL), 5 Holstein cows in early lactation received daily i.m. injections of $1 \mathrm{mg}$ of quinagolide, a suppressor of PRL release, for 9 wk, whereas 4 control cows received the vehicle (water) only. During the last week of treatment, one udder half was milked once a day $(1 \times)$ and the other twice a day $(2 \times)$. Mammary biopsies were harvested $1 \mathrm{wk}$ before and 4 and 8 wk after the start of quinagolide treatment. The quinagolide injections reduced milk yield and resulted in lower levels of $\kappa$-casein and $\alpha$-lactalbumin mRNA in the mammary biopsies at wk 4 compared with the control cows. In the mammary tissue of the quinagolide-treated cows at wk 8 of treatment, cell proliferation (as determined by proliferating cell nuclear antigen labeling) was lower and apoptosis (as determined by the terminal deoxynucleotidyl transferase-mediated dUTP nick-end labeling assay) was higher than in the mammary tissue of the control cows. During differential milking, mammary epithelial cells (MEC) were extracted from the milk by centrifugation and purified by immunocytochemical binding to allow variations in the levels of mammary transcripts to be observed. After 9 wk of treatment, levels of $\alpha$-lactalbumin and $\kappa$-casein mRNA were lower in the MEC isolated from milk of the quinagolide-treated cows. This effect was associated with lower PRL receptor mRNA levels and a tendency toward lower viability in the milk-isolated MEC from the $2 \times$-milked glands. The decrease from $2 \times$ milking to $1 \times$ milking also downregulated $\alpha$-lactalbumin and $\kappa$-casein transcripts in the milk-isolated MEC. Viability was higher for the MEC collected from the $1 \times$-milked udder halves compared with the $2 \times$-milked halves. In
\end{abstract}

Received April 18, 2011.

Accepted September 9, 2011.

${ }^{1}$ Corresponding author: Marion.Boutinaud@rennes.inra.fr conclusion, the reduction in milk yield after chronic administration of the PRL-release inhibitor quinagolide is associated with a reduction in mammary cell activity, survival, and proliferation in lactating dairy cows. Reduced milking frequency was also associated with a decrease in MEC activity.

Key words: prolactin, proliferation, apoptosis, milk mammary epithelial cell

\section{INTRODUCTION}

Milk production depends on both the activity and the number of mammary epithelial cells (MEC). Changes in the number of cells in the mammary gland during lactation are caused by mammary cell turnover resulting from 2 opposing mechanisms, cell proliferation and cell death (mainly through apoptosis). The decline in milk production after the peak of lactation appears to be due to a gradual reduction in the number of milksecreting cells, given that the rate of proliferation is lower than the rate of apoptosis (Knight and Wilde, 1987; Capuco et al., 2003). The mechanisms that are responsible for the variations in the activity and number of mammary cells during lactation are still poorly understood in ruminants.

Prolactin (PRL), whose release by pituitary lactotrophs is enhanced after teat stimulation at milking, is the hormone traditionally presumed to play a major role in the maintenance of lactation. In rodents and rabbits, the inhibition of PRL release during lactation was found to clearly inhibit lactation (Taylor and Peaker, 1975; Travers et al., 1996). In contrast, studies performed in cows and goats showed controversial results regarding the galactopoietic role of PRL in these species (Knight, 2000). Thus, in ruminants, the role of PRL during lactation had not been clear until a recent experiment using an efficient inhibitor of PRL release, the dopamine D2 receptor agonist quinagolide, showed that PRL potentially plays a role in the maintenance of lactation (Lacasse et al., 2011). However, the mecha- 
nism by which the PRL inhibitor reduces milk production remains to be determined.

Although the in vivo evidence for a galactopoietic role of PRL in ruminants is scarce, PRL clearly modulates the activity and number of ruminant mammary cells in vitro. Prolactin stimulates the synthesis of milk in ruminant mammary explants or cultivated MEC (Skarda et al., 1982; Choi et al., 1988). Prolactin also stimulates the proliferation of bovine MEC (Olazabal et al., 2000) and protects them from apoptosis (Accorsi et al., 2002). Despite those findings, the role of PRL in mammary cell activity, survival, and proliferation has not yet been clearly shown in vivo. Indeed, the administration of PRL did not modify cell turnover in bovines (Wall et al., 2006). Our assumption is that, in ruminants, supplementation of the basal level of PRL by exogenous administration is not able to modify mammary functions, whereas endogenous PRL release at milking modulates the activity and number of mammary cells.

Reducing milking frequency from twice daily $(2 \times)$ to once daily $(\mathbf{1} \times)$ was shown to cause a 10 to $30 \%$ decrease in milk yield associated with changes in MEC activity (Littlejohn et al., 2010; Ben Chedly et al., 2011). Indeed, the reductions in milk, lactose, protein, and fat yields caused by $1 \times$ milking are clearly associated with a reduction in milk protein mRNA levels (Ben Chedly et al., 2011). The reduction in milk yield caused by PRL inhibition could be triggered by similar cellular mechanisms.

We are interested in gaining a better understanding of the effect of milking-induced PRL release on mammary gland functions. To assess the effect of PRL, we inhibited its secretion with quinagolide injections. The purpose of this study was to evaluate whether PRL acted on the activity, survival, and proliferation of epithelial cells in the bovine mammary gland and whether the reduction to $1 \times$ milking triggered similar mechanisms.

\section{MATERIALS AND METHODS}

\section{Animals and Experimental Procedures}

All the procedures used on animals were approved by the animal care committee of the French Ministry of Agriculture in accordance with French regulations (Decree No. 2001-464; May 29, 2001).

The experimental design and procedures were described by Lacasse et al. (2011). Briefly, 10 Holstein cows at $62 \pm 4$ DIM and housed at the Mejusseaume experimental farm of the Institut national de la recherche agronomique (INRA, Le Rheu, France) were milked twice a day for a 9-wk period that consisted of a 1-wk pretreatment period and $8 \mathrm{wk}$ of treatment. During wk 9 of treatment, the cows were subjected to 1 wk of differential milking $(1 \times$ milking in one udder half and $2 \times$ milking in the other half).

During the 9 -wk treatment period, 5 of the cows received daily (at $1000 \mathrm{~h}$ ) i.m. injections of $1 \mathrm{mg}$ of quinagolide (Ferring, Wallisellen, Switzerland) diluted in water, and the other 5 cows received water injections (control). One multiparous cow was withdrawn from the control group for health reasons.

\section{Mammary Biopsies}

Biopsies were taken from the upper portion of the mammary gland 1 wk before and 4 and 8 wk after the start of quinagolide treatment. The first 2 mammary biopsies were obtained using a 12-gauge, $10-\mathrm{cm}$, 22-mm Bard Monopty disposable core biopsy instrument (Bard, Voisins-le-Bretonneux, France), and the last biopsy, at $8 \mathrm{wk}$, was obtained using the $70 \times 4$ mm instrument described by Farr et al. (1996). Before the tissue biopsies, local anesthesia was applied by s.c. injection of $40 \mathrm{mg}$ of Xylocaine (Astra France, RueilMalmaison, France). A skin incision was performed with a scalpel. The $22-\mathrm{mm}$ core instrument was inserted 2 or 3 times to obtain sufficient tissue, whereas the $70-\mathrm{mm}$ instrument was inserted only once. After the tissue collection using the 70-mm instrument, a $4-\times 5$-cm plug of absorbable hemostat (Surgicel, Johnson \& Johnson Medical, Ethicon, Issy-les-Moulineaux, France) was inserted into the wound using a syringe (Terumo 6\% Luer, Fisher Bioblock, Illkirch-Graffenstaden, France). A soft gauze pad was applied with pressure to the udder to control hemorrhage. The skin incision was closed with a disposable skin stapler (Royal 35W, Clinique Vétérinaire, Saint-Grégoire, France). The cows received an antibiotic by means of an i.m. injection of $0.6 \mathrm{~g}$ of Excenel (Pfizer Santé Animale, Paris, France) for 3 d.

Mammary tissues obtained $1 \mathrm{wk}$ before and $4 \mathrm{wk}$ after the start of quinagolide treatment were used for RNA extraction only. The biopsies performed after 8 wh were rinsed in sterile saline solution to remove all traces of blood and cut into 2 parts, one of which was immediately frozen in liquid nitrogen and stored at $-80^{\circ} \mathrm{C}$ for separate RNA, DNA, and protein analyses. The other part was washed in PBS and fixed in $4 \%$ paraformaldehyde for immunohistochemical analysis. The fixed tissue was cryoprotected by incubation for $48 \mathrm{~h}$ in a $40 \%$ sucrose solution and then coated with Tissue-Tek O.C.T. compound (Sakura Finetek Europe, LaboNord, Templemars, France), frozen in a cooled bath of isopenthane, and stored at $-80^{\circ} \mathrm{C}$ until use. 


\section{Isolation of MEC from Milk}

Milk epithelial cells were prepared once during the differential milking period. Milk from the morning milking was collected separately for each udder half to prepare total milk cells. Then, epithelial cells were isolated from total milk cells as described previously by Boutinaud et al. (2008), with some modifications. Briefly, $2.3 \mathrm{~kg}$ of fresh milk was defatted by $15 \mathrm{~min}$ of centrifugation at $1,500 \times g$ at $4^{\circ} \mathrm{C}$ in several 230 $\mathrm{mL}$ tubes (VWR International, Fontenay-sous-Bois, France). The skim milk was removed, and the remaining total cell pellet was resuspended and pooled in $150 \mathrm{~mL}$ of PBS (Gibco, Invitrogen, Cergy Pontoise, France). The cell suspension was washed twice in PBS, filtered, and finally resuspended in $2 \mathrm{~mL}$ of PBS containing $1 \%$ BSA (Sigma Aldrich, Lyons, France). This cell suspension was analyzed for cell count and viability determinations using Kova slides (CLM, Nemours, France) under light microscopy and a Vi-CELL XR analyzer (Beckman Coulter, Roissy, France). The 1\% BSA-PBS cell suspension was used for MEC isolation with an immunomagnetic separation technique. Briefly, Dynabeads (Pan Mouse IgG, Dynal Biotech, Invitrogen) were first coated with a primary mouse monoclonal antibody directed against cytokeratin 8 antibody (clone K8.13, Sigma Aldrich). Each cell sample was incubated with the bead and antibody mix. After $1 \mathrm{~h}$ of incubation, the samples were placed in a magnetic particle concentrator (MPC-S, Dynal Biotech, Invitrogen), and the supernatant containing the nonselected cells was removed. The isolated MEC were resuspended in $1 \mathrm{~mL}$ of $1 \%$ BSA-PBS. This cell suspension was analyzed for cell count and viability determinations. The MEC were pelleted by centrifugation $\left(5 \mathrm{~min}, 4^{\circ} \mathrm{C}, 5,000 \times g\right)$, and 1 $\mathrm{mL}$ of Trizol (Invitrogen Life Technologies) was added. The cell samples were mixed and stored at $-80^{\circ} \mathrm{C}$ until total RNA extraction was performed.

\section{Real-Time Reverse-Transcription PCR}

Extraction of total RNA from the mammary tissue samples and milk-isolated MEC samples was performed as previously reported (Boutinaud et al., 2008). The concentration of total RNA was analyzed by spectrophotometry, and the integrity of total RNA given by the RNA integrity number was checked using a 2100 Bioanalyzer (Agilent Technologies, Massy, France). Treatment of total RNA samples (from $500 \mathrm{ng}$ for both types of samples) for reverse transcription and realtime PCR analysis using SYBR Green PCR Master Mix (Applied Biosystems, Foster City, CA) was carried out as described previously (Boutinaud et al., 2008). The primers used for real-time PCR for proliferating cell nuclear antigen (PCNA), (forward 5'-TTTGCACGTATATGCCGAGATC-3'; reverse 5'-TATGGCAACAGCTTCCTCCTC-3'), for PRL receptor (PRLR) long isoform (forward 5'-TGCTGTCATCTGTTTGATTATGGTC-3'; reverse 5'-TTGCTCCGTGTGTTCTTTGG-3'), and for PRLR short isoform (forward 5'-GCTATAGCATGGTGACCTGCATC-3'; reverse 5'-CGGACTTGCCCTCCTATTAAAAC-3') were designed using the Primer Express 1.0 software program (Applied Biosystems) and synthesized by MWG Biotech (Roissy, France). The other primers used were described in previous studies (Boutinaud et al., 2008; Ben Chedly et al., 2009). For each gene analyzed, a standard curve made with serial dilutions of one sample of mammary gland reverse transcript was used to quantify the mRNA levels. The mRNA levels of the studied genes were expressed relative to a housekeeping gene. The genes cyclophilin, R18S, GAPDH, and ribosomal protein large P0 (RPLP0) were evaluated as potential housekeeping genes. The BestKeeper (Pfaffl et al., 2004) and NormFinder (Andersen et al., 2004) programs were used to assess the variability of the candidate housekeeping genes. These analyses indicated that RPLP0 was the most stable housekeeping gene in this experiment. For each gene, the mRNA level was expressed as a semi-absolute mRNA molecule number (Boutinaud et al., 2004). For each target gene, the results were expressed as a ratio using the selected housekeeping gene, namely RPLP0.

\section{Protein Extraction and Western Blot Analysis}

Total and nuclear proteins were extracted from frozen mammary gland tissues after 8 wk of quinagolide treatment. Total proteins were extracted using T-PER Tissue Protein Extraction Reagent (Pierce, Perbio Science, Brebières, France). Frozen mammary tissue samples $(15 \mathrm{mg}$ ) were homogenized in 40 volumes (wt/ vol) of T-PER lysis buffer using an Ultra-Turrax homogenizer (Fisher Bioblock) as recommended by the manufacturer. After centrifugation at $10,000 \times g$ for $5 \mathrm{~min}$ at $4^{\circ} \mathrm{C}$, the supernatant containing the total protein extracts was recovered and quickly frozen. To obtain nuclear protein extracts, frozen mammary tissue samples $(20 \mathrm{mg})$ were homogenized in 5 volumes (wt/vol) of Cytoplasmic Extraction Reagent I from the NE-PER Nuclear and Cytoplasmic Extraction Reagent Kit (Pierce) using an Ultra-Turrax homogenizer. After the tubes were vortexed vigorously, the lysates were incubated on ice for 10 min. Cytoplasmic Extraction Reagent II (5\%) was added to the lysates to disrupt the cell membranes and release the cytoplasmic contents. The intact nuclei were recovered from the cytoplasmic extract by centrifugation at $13,000 \times g$ for $5 \mathrm{~min}$ at 
$4^{\circ} \mathrm{C}$. The pellet was resuspended in $100 \mu \mathrm{L}$ of ice-cold Nuclear Extraction Reagent. The tubes were vortexed and incubated on ice for $40 \mathrm{~min}$ as recommended by the manufacturer. The nuclear preparation was cleared by centrifugation at $13,000 \times g$ for $10 \mathrm{~min}$. The supernatant containing the nuclear extract was quickly frozen. The protein concentration was determined by the Lowry method using the DC Protein Assay Kit (Pierce) as described by the manufacturer. Then, the protein lysates were combined with sample buffer containing $50 \mathrm{~m} M$ Tris- $\mathrm{HCl}$, pH 6.8 (Bio-Rad, Marnesla-Coquette, France), 2\% SDS, $0.1 \%$ bromophenol blue (Sigma Aldrich), 20\% glycerol (Fisher Scientific Bioblock), and $5 \% \beta$-mercaptoethanol (Sigma Aldrich), boiled for $5 \mathrm{~min}$ at $95^{\circ} \mathrm{C}$, and resolved by SDS-PAGE. Proteins $(30 \mu \mathrm{g}$ per lane) and prestained molecular mass standards (Fermentas, Saint-Rémy-lès-Chevreuse, France) were separated on $10 \%$ SDS-polyacrylamide gels, electro-transferred overnight to polyvinylidene difluoride membranes (Amersham Biosciences, Orsay, France), and incubated with blocking solution [5\% dry skim milk dissolved in Tris-buffered saline-Tween 20 (Bio-Rad), $50 \mathrm{~m} M$ Tris-HCl pH 8.6 (Bio-Rad), 150 $\mathrm{m} M \mathrm{NaCl}$ (Sigma Aldrich), and $0.1 \%$ Tween (Sigma Aldrich)] for $30 \mathrm{~min}$. The membranes were then incubated overnight at $4^{\circ} \mathrm{C}$ with the appropriate dilution of the following primary antibodies: a mouse monoclonal anti-PCNA (clone PC10, DakoCytomation, Glostrup, Denmark; diluted 1:5,000) and a mouse monoclonal anti- $\beta$-actin (A5441, Sigma Aldrich; diluted 1:5,000). Then, the membranes were washed with Tris-buffered saline-Tween 20 before incubation with horseradish peroxidase-conjugated anti-mouse secondary antibodies (31450, Pierce) for $1 \mathrm{~h}$ at room temperature. Peroxidase activity was detected using an enhanced chemiluminescence detection system (ECL System, Amersham Biosciences). The membranes were exposed to Curix Ortho HT-G films (Agfa, Mortsel, Belgium), which were then digitized at 16-bit/600-dpi resolution using a Canoscan D1250U2 scanner (Canon, Courbevoie, France). The images were saved as TIFF files and calibrated to an optical density scale. The integrated optical density of the bands was quantified using the ImageJ software program (Wayne Rasband, National Institutes of Health, Bethesda, MD). Each sample was normalized according to $\beta$-actin content.

\section{Immunohistochemistry for Proliferation and Apoptosis Assays in Mammary Tissue Sections}

Proliferating cells were identified in mammary tissue after 8 wk of quinagolide treatment as cells expressing the PCNA antigen, as previously reported (Colitti et al., 2005). Cryosections measuring $7 \mu \mathrm{m}$ thick were mounted onto Superfrost/Plus slides (Prolabo, Bondoufle, France). Mammary gland sections were quenched in PBS with 3\% hydrogen peroxide and $10 \%$ methanol for 30 min. After several washes with PBS, the sections were permeabilized with $1 \%$ SDS-PBS for $5 \mathrm{~min}$, washed 3 times in PBS, and pre-incubated in $1 \%$ BSA-PBS for $1 \mathrm{~h}$ at room temperature. The tissues were then incubated in the presence or absence of a primary antibody (M0879, monoclonal mouse clone PC10, DakoCytomation; diluted 1:200) in the same buffer overnight at $4^{\circ} \mathrm{C}$. After washes with $1 \% \mathrm{BSA} /$ PBS, the samples were incubated with 1:200-diluted second antibody (F5387, goat anti-mouse fluorescein isothiocyanate-conjugated antibody, Sigma Aldrich) for $1 \mathrm{~h}$ at room temperature. Subsequently, the mammary gland sections were counterstained for $3 \mathrm{~min}$ with 4',6-diamidino-2-phenylindole (DAPI, D9542, Sigma Aldrich) at $33 \mu \mathrm{g} / \mathrm{mL}$ and then for $3 \mathrm{~min}$ with propidium iodide (P4864, Sigma Aldrich) at $333 \mu \mathrm{g} /$ $\mathrm{mL}$.

The determination of apoptosis in the mammary gland biopsies was based on DNA fragmentation detection using terminal deoxynucleotidyl transferase-mediated dUTP nick-end labeling (TUNEL) staining. Cryosections measuring $7 \mu \mathrm{m}$ thick that had been mounted onto slides treated with 3-aminopropyltriethoxysilane (Sigma Aldrich) were thawed and incubated for $30 \mathrm{~min}$ at $70^{\circ} \mathrm{C}$ in a solution of $10 \mathrm{~m} M$ citrate sodium (Sigma Aldrich) and 0.1\% Triton (Fisher Scientific Bioblock), washed in PBS, and incubated for $30 \mathrm{~min}$ at $37^{\circ} \mathrm{C}$ in $200 \mathrm{ng} / \mu \mathrm{L}$ proteinase K solution (Promega, Madison, WI). The tissue sections were incubated with reagents from the DeadEnd Fluorometric TUNEL System (Promega) according to the manufacturer's instructions. After the TUNEL reaction was stopped, the mammary gland sections were counterstained by incubation for 3 min with DAPI (Sigma Aldrich) at a concentration of $333 \mu \mathrm{g} / \mathrm{mL}$.

After washing, the slides were mounted with Vectashield (Valbiotech, Paris, France) and examined under fluorescence microscopy using an Eclipse E400 microscope (Nikon France, Le Pallet, France). The pictures were captured by a DXM 1200 digital still camera (Nikon) and analyzed with the ImageJ software. Eight microscopic fields (magnification: $200 \times$; area: $0.14 \mathrm{~mm}^{2}$ per microscopic field) were examined for each tissue sample. The percentage of apoptosis or proliferation in the mammary gland was determined as a ratio of the TUNEL-labeled or PCNA-positive cells to the DAPIcounterstained nuclei. Epithelial cells positive for PCNA were determined with propidium iodide staining, which draws the outlines of the acini. For each acinus, the ImageJ software was used to count the number of cells and determine alveolar size. 


\section{DNA Quantification of Mammary Tissue}

Mammary tissue samples $(50 \mathrm{mg}$ ) were first weighed and homogenized in $2.5 \mathrm{~mL}$ sodium phosphate extraction buffer $\left(0.05 \mathrm{M} \mathrm{Na}_{2} \mathrm{HPO}_{4}, 0.05 \mathrm{M} \mathrm{NaH}_{2} \mathrm{PO}_{4}, 2 \mathrm{mM}\right.$ EDTA, and $2 \mathrm{M} \mathrm{NaCl}$, pH 7.4, Sigma Aldrich). Then, the mixture was ground using an Ultra-Turrax homogenizer, sonicated for $1 \mathrm{~min}$, and centrifuged at 4,000 $\times$ $g$ for $1 \mathrm{~h}$. The supernatant was transferred to another tube, and the pellet was resuspended in $2.5 \mathrm{~mL}$ of the extraction buffer. Subsequently, the pellet was subjected to 3 successive extraction steps, namely grinding, sonication, and centrifugation, as described above. At the end of each centrifugation, the supernatant was recovered and added to the first. The DNA concentration in the mixture was determined by fluorescence using Hoechst 33258 dye (Sigma Aldrich). Aliquots of the DNA mixture were mixed with sodium phosphate buffer stained with Hoechst dye to a final dye concentration of $1 \mu \mathrm{g} / \mathrm{mL}$. The reactions were performed in a $200-\mu \mathrm{L}$ final volume in a black 96 -well microplate. Serial dilutions of calf thymus DNA (Sigma Aldrich) were used to generate a standard curve. The plates were directly read with the Mithras LB940 fluorescence plate reader (Berthold Technologies, Thoiry, France) at 355 $\mathrm{nm}$ excitation and $460 \mathrm{~nm}$ emission wavelengths. The DNA concentrations in the mammary tissue samples were calculated by extrapolation from the standard curve and correction for aliquot volume.

\section{Statistical Analyses}

The statistical analyses of the real-time PCR results were performed on the basis of semi-absolute data normalized individually by RPLP0 multiplied by $10^{4}$ and $\log _{10}$-transformed. The PCR data for the biopsy samples were analyzed by ANOVA using the MIXED procedure of SAS (SAS Institute Inc., Cary, NC) with a REPEATED statement. Time was used as a repeated effect, and cow(treatment) was used as the subject. The data for cell proliferation and apoptosis, protein and DNA contents, and alveolar characteristics in the mammary gland were analyzed by ANOVA using the MIXED procedure of SAS. The proliferation rate obtained in the entire mammary tissue was compared with that in the MEC by testing the $\mathrm{H}_{0}$ hypothesis that the rates did not differ using a paired Student's $t$-test. The data for the PCR results in the milk-isolated MEC were analyzed by least squares ANOVA using the GLM procedures in the epsilon Windows software (L. Delaby, UMR1080, Production du lait, INRA, France). The split-plot linear model was used to test the effects of milking frequency, quinagolide treatment, quinagolide treatment within the cow, and the interaction between milking frequency and quinagolide treatment. Differences were considered statistically significant when $P$ $<0.05$.

\section{RESULTS}

\section{Effects of Quinagolide Treatment and Differential Milking on Milk Yield and Composition}

The results for milk yield and composition were reported previously (Lacasse et al., 2011). Briefly, daily injections of quinagolide reduced milking-induced PRL release $(P<0.05)$ but not basal PRL concentration. Quinagolide induced a faster decline in milk production $(P<0.05)$ compared with the control treatment. The milk production of the quinagolide-treated cows was $5.3 \mathrm{~kg} / \mathrm{d}$ less than that of the control cows during the last 4 wk of treatment. Milk fat, protein, and casein contents were not affected by the treatment, whereas lactose content was reduced $(P<0.05)$ in the quinagolide-treated cows in wk 5, 6, and 7. Milk fat, lactose, and protein yields were lower in the quinagolide-treated animals than in the controls $(P<0.05)$.

Differential milking resulted in modifications in milk yield and composition. Reductions in milk production and fat and protein yields were observed in the $1 \times$-milked udder halves $(P<0.001)$ compared with the $2 \times$-milked halves. The inhibitory effect of quinagolide was maintained in the $2 \times$-milked udder halves $(P<$ $0.05)$ but was lost in the $1 \times$-milked halves $(P>0.15)$.

\section{Transcript Levels in the Mammary Gland}

Before the start of quinagolide treatment, the levels of $\alpha$-LA and $\kappa-\mathrm{CN}$ mRNA were similar between the 2 groups of animals (Table 1). After 4 wk of treatment, quinagolide injections induced reductions in the $\alpha$-LA and $\kappa-\mathrm{CN}$ mRNA levels $(-73 \%, P=0.06$ and $-75 \%, P$ $=0.05$, respectively). The mRNA levels of these genes were not different after $8 \mathrm{wk}$ of treatment. Quinagolide treatment had no effect on glucose transporter 1 (GLUT1), caspase 3, bax, or bcl 2 mRNA levels in the mammary gland (Table 1). At no time did quinagolide treatment affect PRLR long and short isoform mRNA levels (Table 1) in the mammary tissue.

\section{Number and Transcript Levels of Milk-Isolated MEC}

Mammary epithelial cells were collected from the $1 \times$ - and $2 \times$-milked udder halves during wk 9 of treatment. The number of milk-isolated MEC averaged 14.7 $\times 10^{3} \pm 4.1 \times 10^{3}$ cells $/ \mathrm{mL}$ milk, representing $9.3 \pm$ $1.9 \%$ of the total cells recovered in the milk. The total number of cells was not affected by either quinagolide 
Table 1. Effect of the injection of water (control; $\mathrm{n}=4$ ) or quinagolide (Quin; $1 \mathrm{mg} / \mathrm{d} ; \mathrm{n}=5$ ) on mRNA levels in mammary tissue in wk -1 , 4 , and 8 relative to the start of treatment

\begin{tabular}{|c|c|c|c|c|c|c|c|c|c|}
\hline \multirow[b]{2}{*}{ Item $^{1}$} & \multicolumn{3}{|c|}{ Week -1 } & \multicolumn{3}{|c|}{ Week 4} & \multicolumn{3}{|c|}{ Week 8} \\
\hline & Control & Quin & $P$-value ${ }^{2}$ & Control & Quin & $P$-value ${ }^{2}$ & Control & Quin & $P$-value ${ }^{2}$ \\
\hline$\alpha$-Lactalbumin & 27,000 & 21,900 & 0.76 & 53,700 & 13,600 & 0.06 & 55,500 & 34,000 & 0.49 \\
\hline$\kappa$-Casein & 29,900 & 35,800 & 0.77 & 64,400 & 17,100 & 0.05 & 75,700 & 66,200 & 0.83 \\
\hline PRLR long isoform & 3.2 & 5.3 & 0.43 & 3.8 & 1.7 & 0.20 & 3.7 & 7.3 & 0.28 \\
\hline PRLR short isoform & 30.8 & 33.1 & 0.84 & 28.1 & 24.8 & 0.74 & 33.7 & 46.1 & 0.41 \\
\hline GLUT1 & 2.0 & 1.9 & 0.77 & 1.6 & 1.1 & 0.18 & 2.5 & 2.8 & 0.63 \\
\hline PCNA & 6.9 & 7.7 & 0.63 & 6.5 & 7.8 & 0.41 & 7.7 & 6.7 & 0.48 \\
\hline Caspase 3 & 0.6 & 1.1 & $<0.01$ & 0.9 & 0.7 & 0.18 & 1.5 & 1.3 & 0.52 \\
\hline $\operatorname{Bax}$ & 0.38 & 0.19 & 0.12 & 0.14 & 0.23 & 0.28 & 0.26 & 0.24 & 0.81 \\
\hline $\mathrm{Bcl} 2$ & 0.36 & 0.51 & 0.32 & 0.36 & 0.44 & 0.55 & 0.38 & 0.29 & 0.46 \\
\hline $\mathrm{Bax} / \mathrm{bcl} 2$ & 1.10 & 0.42 & $\leq 0.01$ & 0.47 & 0.54 & 0.75 & 0.78 & 0.86 & 0.70 \\
\hline RPLP0 & 392,000 & 377,000 & 0.87 & 382,000 & 302,000 & 0.33 & 395,000 & 556,000 & 0.17 \\
\hline
\end{tabular}

${ }^{1} \mathrm{PRLR}=$ prolactin receptor; GLUT1 $=$ glucose transporter 1 ; PCNA = proliferating cell nuclear antigen; RPLR0 = ribosomal protein large P0. ${ }^{2}$ Statistical analyses were performed on the semi-absolute mRNA molecule number relative to RPLP0 multiplied by $10^{4}$ and $\log _{10}$-transformed. Data presented are retransformed into the semi-absolute mRNA level ratio multiplied by 100, except for RPLP0, which is expressed as a semiabsolute number of molecules.

treatment or milking frequency. Quinagolide treatment had no effect on the loss MEC in milk per day, whereas this number tended to be lower in the $1 \times$-milked udder halves than in the $2 \times$-milked halves (Table 2 ).

The viability of isolated MEC was not affected by quinagolide but was higher for the cells collected from the $1 \times$-milked udder halves than for those from the $2 \times$-milked halves $(P=0.03$; Table 2$)$. Quinagolide did not affect MEC viability $(P=0.14$; Table 2$)$. When the $2 \times$-milked halves were considered alone, however, quinagolide treatment had a tendency to reduce milkisolated MEC viability compared with the control treatment $(P=0.08)$.

Total RNA recovered from the milk-isolated MEC averaged $34.5 \pm 9.1 \mu \mathrm{g}$. The quality and quantity of total RNA for the milk-isolated MEC samples were good except for one sample that was removed from the trial (RNA integrity number $<4$ ). During the differential milking, the mRNA levels of $\alpha-\mathrm{LA}$ and $\kappa-\mathrm{CN}$ were lower in the milk-isolated MEC from both the $1 \times$ - and $2 \times$-milked udder halves in the quinagolide-treated cows compared with the control cows $(P=0.001$ for both genes; Table 2). Similarly, quinagolide treatment was associated with lower levels of the PRLR long isoform transcript $(P=0.02)$. This effect was significant in the MEC from the $2 \times$-milked udder halves $(P=0.04)$ but not in the MEC from the $1 \times$-milked halves $(P=0.12)$. In contrast, the levels of the PRLR short isoform transcript were not affected by quinagolide treatment $(P=$ 0.13). As in the mammary gland, the mRNA levels of

Table 2. Effect of injection of water (control; $\mathrm{n}=4$ ) or quinagolide (Quin; $1 \mathrm{mg} / \mathrm{d} ; \mathrm{n}=5$ ) and differential milking ( $1 \times$, once-daily milking of one udder half; $2 \times$, twice-daily milking of the other udder half) on mammary epithelial cells (MEC) recovered in milk and on mRNA levels in milk-isolated MEC during wk 9 of quinagolide treatment

\begin{tabular}{|c|c|c|c|c|c|c|c|}
\hline \multirow[b]{2}{*}{ Item $^{1}$} & \multicolumn{2}{|c|}{$2 \times$} & \multicolumn{2}{|c|}{$1 \times$} & \multicolumn{3}{|c|}{$P$-value ${ }^{2}$} \\
\hline & Control & Quin & Control & Quin & MF & Quin & MF $\times$ Quin \\
\hline $\mathrm{MEC} / \mathrm{mL}$ of milk & 14,166 & 17,799 & 14,166 & 12,551 & 0.52 & 0.80 & 0.52 \\
\hline Milk MEC viability (\%) & $77.5^{\mathrm{ab}}$ & $51.3^{\mathrm{a}}$ & $91.7^{\mathrm{b}}$ & $87.2^{\mathrm{b}}$ & 0.03 & 0.14 & 0.28 \\
\hline Loss of MEC in the milk $\left(10^{6}\right.$ cells $\left./ \mathrm{d}\right)$ & 309 & 288 & 172 & 131 & 0.06 & 0.66 & 0.89 \\
\hline$\alpha$-Lactalbumin & $1,313^{\mathrm{a}}$ & $156^{\mathrm{b}}$ & $316^{\mathrm{b}}$ & $53^{\mathrm{c}}$ & $\leq 0.01$ & $\leq 0.01$ & 0.57 \\
\hline$\kappa$-Casein & $365^{\mathrm{a}}$ & $41^{\mathrm{b}}$ & $143^{\mathrm{a}}$ & $20^{\mathrm{b}}$ & 0.04 & $\overline{<} 0.01$ & 0.75 \\
\hline PRLR long isoform & $0.39^{\mathrm{a}}$ & $0.06^{\mathrm{b}}$ & $0.16^{\mathrm{ab}}$ & $0.05^{\mathrm{b}}$ & 0.31 & 0.02 & 0.51 \\
\hline PRLR short isoform & 0.13 & 0.05 & 0.09 & 0.02 & 0.38 & 0.13 & 0.73 \\
\hline GLUT1 & 1.65 & 1.15 & 1.87 & 1.77 & 0.38 & 0.49 & 0.61 \\
\hline Bax & 1.75 & 2.23 & 2.60 & 2.75 & 0.28 & 0.58 & 0.71 \\
\hline Bcl 2 & 2.44 & 2.69 & 2.53 & 2.06 & 0.49 & 0.74 & 0.38 \\
\hline $\mathrm{Bax} / \mathrm{bcl} 2$ & 0.71 & 0.60 & 0.92 & 1.12 & 0.12 & 0.93 & 0.51 \\
\hline RPLP0 & 291,000 & 300,000 & 367,000 & 330,000 & 0.31 & 0.80 & 0.67 \\
\hline
\end{tabular}

${ }^{\mathrm{a}-c}$ For significant difference according to $\mathrm{MF} \times$ Quin treatments.

${ }^{1} \mathrm{PRLR}=$ prolactin receptor; GLUT1 $=$ glucose transporter $1 ;$ RPLR0 $=$ ribosomal protein large P0.

${ }^{2}$ Statistical analyses were performed on the semi-absolute mRNA molecule number relative to RPLP0 multiplied by $10^{5}$ and $\log _{10}$-transformed. Data presented here are retransformed into the semi-absolute mRNA level ratio multiplied by 100, except for RPLP0, which is expressed as a semi-absolute number of molecules. Effects: $\mathrm{MF}$ = milking frequency; Quin = quinagolide. 
GLUT1, caspase 3, bax, and bcl 2 were not affected by quinagolide treatment in the milk-isolated MEC.

As with quinagolide treatment, milking frequency induced variations in milk protein mRNA levels in the milk-isolated MEC (Table 2). Transcripts of $\alpha$-LA and $\kappa-\mathrm{CN}$ were downregulated by $1 \times$ milking compared with $2 \times$ milking $(P \leq 0.01$ and $P=0.04$ for $\alpha$-LA and $\kappa-\mathrm{CN}$, respectively). The mRNA levels of the other studied genes did not vary with milking frequency in the milk-purified MEC.

\section{PCNA Protein and mRNA Expression and Proliferation Rate in the Mammary Gland}

Analysis by Western blotting of PCNA protein levels in the mammary gland tissue collected in wk 8 revealed 1 PCNA band of $36 \mathrm{kDa}$ expressed in the total and nuclear protein extracts (Figure 1). Relative PCNA protein levels were lower in the total and nuclear protein extracts from the quinagolide-treated cows compared with the controls $(P=0.01$ and $P=0.03$, respectively). In contrast, PCNA mRNA levels analyzed by real-time reverse transcription PCR were not affected by quinagolide treatment (Table 2). The immunohistochemistry analysis showed that PCNA labeling was principally localized in the nuclei. The counting of PCNA-positive cells indicated that the percentage of proliferation in the mammary gland was lower in the quinagolide-treated cows than in the controls $(-50 \%, P=0.02$; Figure 2$)$. The reduction in the percentage of PCNA-positive cells averaged $-57 \%(P=0.01)$ when only the MEC were considered. Interestingly, the proliferation rate tended to be higher in the MEC than in the entire mammary gland of both groups of animals $(P=0.08)$.

\section{Apoptosis, Alveolar Structure, and DNA Concentration in the Mammary Gland}

In the mammary biopsies collected after 8 wk of treatment, the level of apoptosis determined using the TUNEL assay was 3 times higher in the quinagolidetreated cows than in the controls $(P \leq 0.01$; Figure 2).

Quinagolide treatment had no effect on the size of the alveoli, which averaged $7,200 \pm 1,360$ and 7,010 $\pm 600 \mu^{2}{ }^{2}(P=0.90)$ for the controls and the quinagolide-treated cows, respectively. Similarly, the number of cells per alveolus and the number of alveoli per microscopic field did not vary with quinagolide treatment, averaging $40.5 \pm 2.3$ and $45.6 \pm 8.3(P=0.61)$ and $6.2 \pm 0.6$ and $7.0 \pm 0.9(P=0.545)$ for the controls and the quinagolide-treated cows, respectively. Moreover, mammary DNA concentration did not vary with quinagolide treatment, averaging $1.31 \pm 0.15$ and 1.06 $\pm 0.70 \mathrm{mg} / \mathrm{g}$ of tissue $(P=0.32)$ for the controls and the quinagolide-treated cows, respectively.

\section{DISCUSSION}

This experiment studied the mechanisms by which quinagolide treatment reduces milk production in dairy cows. The decrease in milk yield induced by quinagolide treatment was accompanied by a decrease in $\alpha-\mathrm{LA}$ and $\kappa$-CN mRNA levels in the mammary biopsies after 4 wk of treatment. The effects of quinagolide on milk protein transcripts may be responsible for the reduced synthesis of milk protein and lactose. Incidentally, protein and lactose yields were lower in the quinagolidetreated cows. The effect of quinagolide treatment on lactose secretion via the downregulation of the $\alpha-\mathrm{LA}$ gene, which encodes the coenzyme of lactose synthase, could explain, in part, the lower milk production with quinagolide, given that lactose is the major osmotic agent in milk and therefore a regulator of milk volume. The downregulation of milk protein transcripts is a good indication that mammary cell activity was decreased by quinagolide.

The effect of quinagolide on milk protein transcripts is probably due to the inhibition of the milking-induced PRL release (Lacasse et al., 2011). Previous studies reported that PRL stimulates milk protein expression in bovine MEC (Choi et al., 1988) and that PRL injections enhance $\alpha$-LA mRNA expression in the mammary gland of dairy cows in early lactation (Wall et al., 2006). It is well established that the peak of PRL at parturition is necessary for the initiation of lactation. Suppression of the PRL surge at parturition inhibits mammary cell differentiation and lactogenesis (Akers et al., 1981a,b). Therefore, the milking-induced PRL release may help maintain the differentiation state of mammary cells during lactation.

Although the effect of quinagolide on milk production was still present, the effect on milk protein mRNA in the mammary tissue was no longer significant after 8 wk of treatment. Conversely, lower levels of $\alpha-\mathrm{LA}$ and $\kappa-\mathrm{CN}$ mRNA were still observed in the milk-isolated MEC from the quinagolide-treated cows compared with the controls after 9 wk of treatment. In contrast to milk-isolated MEC, the mammary tissue contains other types of cells (myoepithelial cells, endothelial cells, adipocytes, and fibroblasts), and the extraction of RNA from the mammary tissue may dilute the mammary transcripts of interest among transcripts from other types of cells. Thus, the purification of MEC from milk could constitute a more accurate method than the collection of mammary tissue for observing small variations in transcript levels. Thus, the lack of significant 
Control

Quinagolide

\section{A}

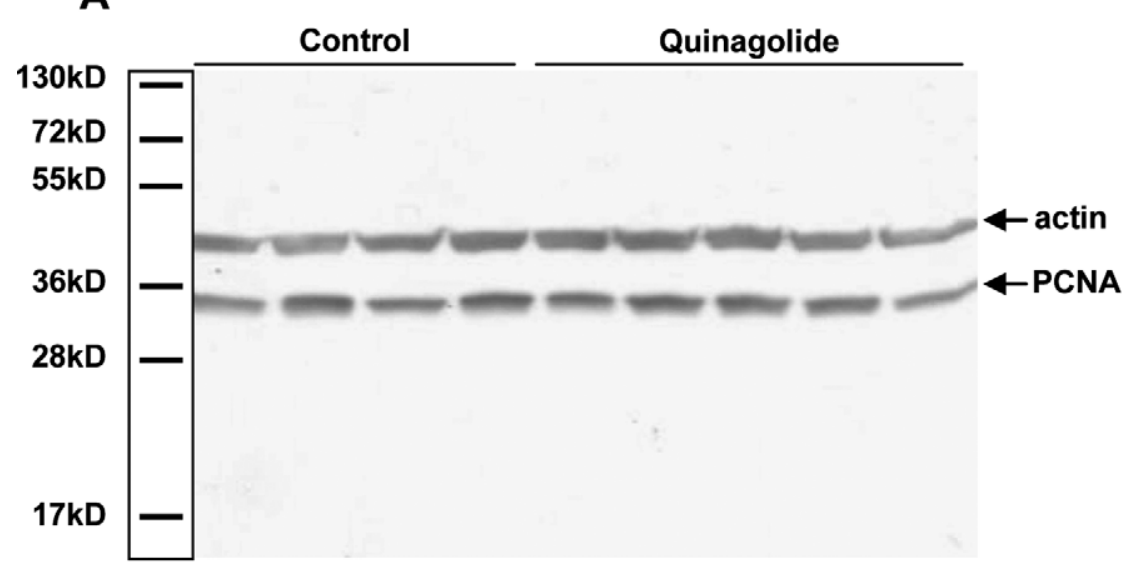

B

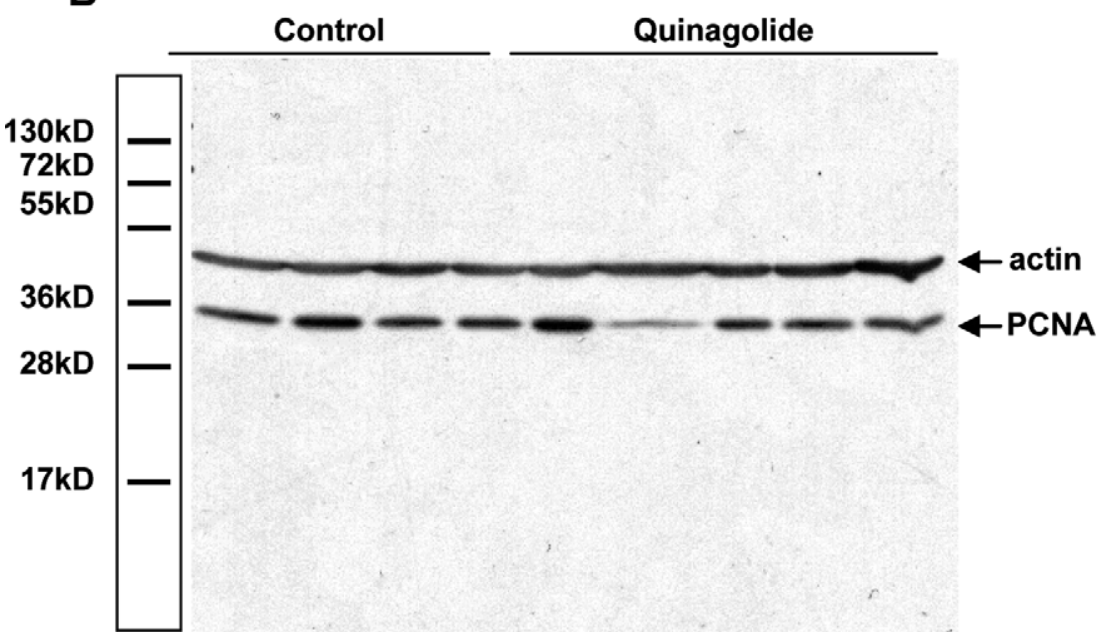

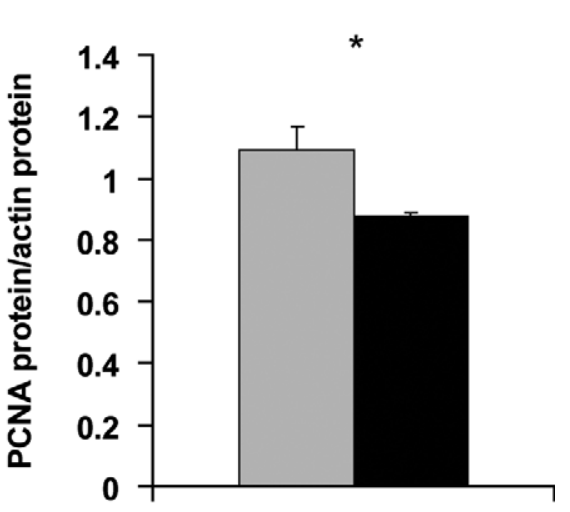

Total extract

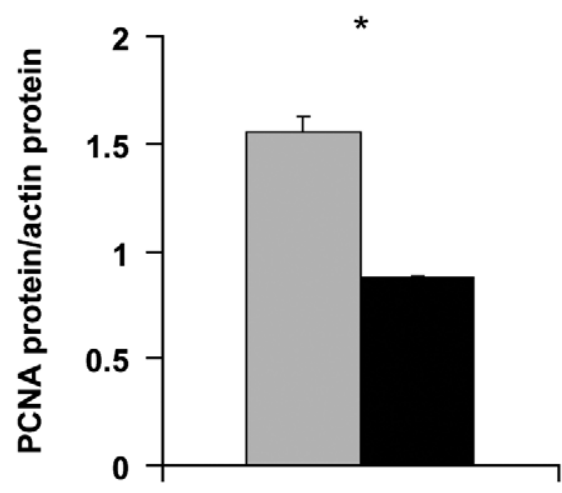

Nuclear extract

Figure 1. Western blot analyses of proliferating cell nuclear antigen (PCNA) and $\beta$-actin in total (panel A) and nuclear (panel B) protein extracts from the mammary gland of cows treated $(n=5)$ or not $(n=4)$ with quinagolide for 8 wk. The integrated optical density of bands was quantified using the ImageJ software program (National Institutes for Health, Bethesda, MD) and normalized to $\beta$-actin. The bars represent the mean \pm SEM for each type of protein extract for the control cows and the quinagolide-treated cows. ${ }^{*} P<0.03$.

effect of the PRL inhibitor on milk protein mRNA levels after 8 wk of treatment could be attributed to the difficulty inherent in analyzing mRNA variations in a complex tissue.

Because glucose, the major precursor for lactose synthesis, is actively transported into the mammary cells, it is possible that reduced expression of the main mammary glucose transporter, GLUT1, is involved in the reduction of lactose synthesis. In rats, PRL deprivation induced a $40 \%$ decrease in the GLUT1 protein level in the mammary gland plasma membrane, whereas the mRNA level was not affected (Fawcett et al., 1992). Although quinagolide treatment decreased lactose yield and content, it had no effect on GLUT1 mRNA expression in either mammary tissue or milk-purified epithelial cells. Our results suggest that the regulation of lactose synthesis by PRL does not involve the transcriptional regulation of GLUT1.

The second mechanism examined to explain the effect of quinagolide treatment on milk production was the evolution of cell turnover in the mammary gland. The PCNA level is an indicator of the rate of cell proliferation. Quinagolide treatment reduced the amount of PCNA protein, suggesting a lower rate of cell proliferation in the mammary gland. This result is in accordance with the proliferative effect of PRL 


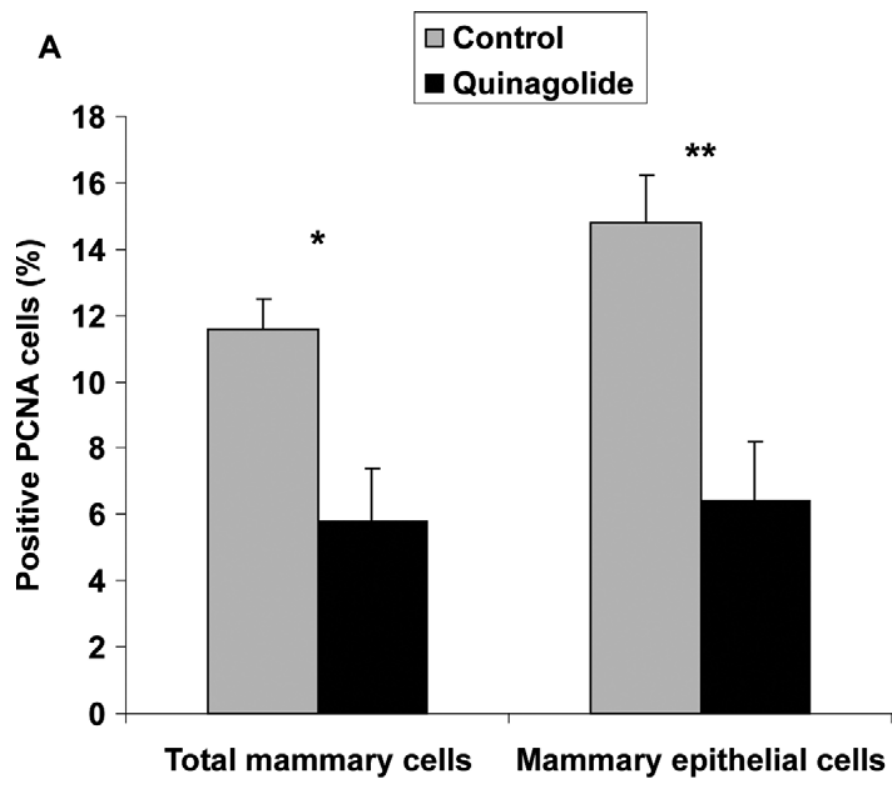

B

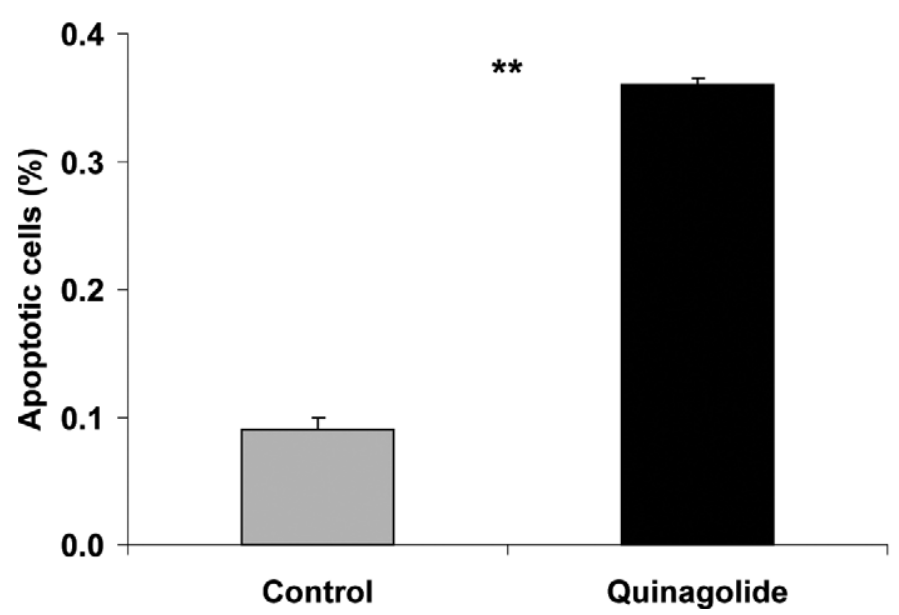

Figure 2. Proliferation (A) and apoptosis (B) in the mammary tissue of control cows $(\mathrm{n}=4)$ and quinagolide-treated cows $(\mathrm{n}=$ 5) for $8 \mathrm{wk}$. The mammary gland sections were first incubated with mouse anti-proliferating cell nuclear antigen antibody and a secondary fluorescein isothiocyanate-conjugated anti-goat antibody and stained with propidium iodide to draw the outline of the epithelium and with 4',6-diamidino-2-phenylindole to counterstain the nuclei (panel A). The mammary gland sections were labeled by the terminal deoxynucleotidyl transferase-mediated dUTP nick-end labeling assay and stained with $4^{\prime}, 6$-diamidino-2-phenylindole to counterstain the nuclei (panel B). ${ }^{*} P<0.05 ;{ }^{* *} P \leq 0.01$.

observed in cultivated bovine MEC (Olazabal et al., 2000). However, this observation is not in line with the findings of Wall et al. (2006), who reported that in vivo injections of exogenous PRL failed to stimulate cell proliferation in the mammary gland in lactating dairy cows. Exogenous PRL may not affect mammary cell proliferation due to the saturation of PRLR, as suggested by Plaut et al. (1987). In contrast with that last study, the present study found that quinagolide treatment reduced endogenous PRL, suggesting that endogenous milking-induced PRL release is important for MEC proliferation during lactation.

The antiproliferative effect of quinagolide has been confirmed by the immunohistological detection of PCNA-positive nuclei. However, the percentage of positive cells was higher than expected. Proliferating cell nuclear antigen is an auxiliary protein for DNA polymerase $\gamma$ that has a long half-life, leading to persistence of staining even in cells that have recently left proliferative status (Yu and Filipe, 1993). Given that the overestimation of the proliferation rate is the same for all samples, however, we believe that this staining has biological significance.

In this experiment, the number of cells labeled by the TUNEL assay suggests that quinagolide treatment caused a higher level of apoptosis in the mammary gland. In agreement, DNA laddering, a marker of cell apoptosis, was observed in bovine mammary explants cultured in the absence of PRL (Accorsi et al., 2002). Our result is also in accordance with a study performed in rats showing that injections of exogenous PRL in animals deficient in growth hormone and PRL inhibited the appearance of DNA laddering in the mammary gland (Travers et al., 1996). Nevertheless, the apoptotic effect of quinagolide was not accompanied by modifications of transcripts involved in cell death, of alveolar structures in the mammary tissue, or of matrix metalloproteinase activities (Lacasse et al., 2011), suggesting that remodeling of mammary tissue did not occur. The microscopic observations and DNA concentrations are probably not sensitive enough to observe variations in the number of cells in the mammary gland. Rather than acting on the number of cells in the alveolus and DNA concentration, PRL could increase the total number of alveoli, the total amount of DNA, and the total weight of mammary gland as was demonstrated for growth hormone action in the mammary gland (Baldi et al., 2002). A better indicator would have been the weight of the mammary gland. Moreover, although the loss of MEC in milk was not affected by it, quinagolide treatment tended to reduce the viability of the MEC collected. Our study provides further evidence that milking-induced PRL release acts as a survival factor for MEC.

Similar to quinagolide treatment, the reduction of milking frequency from $2 \times$ to $1 \times$ induced a significant decrease in $\alpha-\mathrm{LA}$ and $\kappa-\mathrm{CN}$ mRNA levels. The downregulation of milk protein gene expression was already shown in MEC during $1 \times$ milking in cows (Boutinaud et al., 2008; Littlejohn et al., 2010) and goats (Ben Chedly et al., 2011). Similarly, a trend toward higher levels of $\alpha$-LA mRNA was reported when milking fre- 
quency was increased from 2 to 4 times a day (Wall et al., 2006). The absence of an effect of milk frequency on GLUT1 mRNA is in accordance with previous results in cows (Boutinaud et al., 2008; Ben Chedly et al., 2011). As reported for goats (Ben Chedly et al., 2011), the effect of milking frequency on GLUT1 mRNA might appear after more than $7 \mathrm{~d}$ of $1 \times$ milking. The effect of $1 \times$ milking on the regulation of milk protein mRNA expression is not the consequence of a reduced milking-induced PRL release, given that the 2 milking frequencies were performed on the same animal. The effect of milking frequency in our study is due to a local effect only. This local effect could be the consequence of a chemical agent, the feedback inhibitor of lactation, a physical effect due to milk accumulation, or some combination thereof (Knight et al., 1998). Such local effects were found to be responsible for modifications in tight junction opening and increased matrix metalloproteinase activities during $1 \times$ milking; those modifications had not been observed with quinagolide treatment (Lacasse et al., 2011). Thus, the effect of $1 \times$ milking acts partly through mechanisms similar to those involved in quinagolide treatment, namely the decrease in MEC activity.

The effect of milking frequency could be driven by differing PRL sensitivity indicated by changes in PRLR gene expression. The PRLR is expressed as short and long isoforms (Binart et al., 2010), which are differentially expressed or regulated during the estrous cycle and pregnancy (Buck et al., 1992), suggesting that the isoforms may initiate distinct signaling pathways and then mediate different biological effects. The PRLR long isoform is involved in milk protein gene expression (Lesueur et al., 1991), whereas the short isoform is shown to transmit only a mitogenic signal (Das and Vonderhaar, 1995) and could also act as a negative regulator (Berlanga et al., 1997; Perrot-Applanat et al., 1997). Controversial results about the effects of milking frequency and suckling on PRLR mRNA were reported: PRLR mRNA was found to increase during thrice-daily milking compared with $1 \times$ milking or with more frequent suckling in the mammary tissue of cows and rats (Kim et al., 1997; Bernier-Dodier et al., 2010). In our study, however, neither the short nor the long isoform mRNA levels were affected during $1 \times$ milking, as was also observed with milking performed 4 times a day (Wall et al., 2006). As suggested by Wall et al. (2006), the effect of milking frequency on PRLR gene expression is probably acute and could depend on the sampling scheme.

An unexpected result in the present study was the lower level of PRLR mRNA in the milk-isolated MEC from the quinagolide-treated cows, although this result was not observed in the mammary biopsy. This result is in disagreement with the inverse relationship between circulating PRL and the expression of PRLR mRNA in the mammary gland of dry cows exposed to different photoperiods (Auchtung et al., 2005). This discrepancy may result from the difference between the lactating stage and the dry stage in cows. The effect of quinagolide on PRLR may result from a lower differentiation status of epithelial cells in the mammary gland that are less exposed to PRL. This effect could reinforce the effect of PRL deprivation and explain a portion of the decrease in cell activity and the downregulation of milk protein transcripts in the quinagolide-treated cows. The relationship between PRLR expression in the MEC and PRL concentration during lactation should be further studied.

\section{CONCLUSIONS}

In this study, we have shown that the PRL-release inhibitor quinagolide acts through the regulation of MEC milk protein transcription and MEC survival and proliferation in lactating dairy cows. The regulation of milk protein transcription is also involved in short-term milking frequency changes. This study suggests that PRL release at milking is crucial for the maintenance of MEC in a differentiated status in the mammary gland of dairy cows. The specificity of quinagolide actions via PRL inhibition release should be evaluated by testing whether PRL injections in quinagolide-treated cows are able to restore the mammary functions. To confirm these results, some other dopamine agonists known to have strong inhibition effects on PRL release, such as metergoline or cabergoline, could be tested in the future.

\section{ACKNOWLEDGMENTS}

The authors thank P. Lamberton and his team at the Mejusseaume farm (UMR1080, Production du lait, INRA, Le Rheu, France) for taking care of the cows and assisting with blood sampling and injections. We are also grateful to S. Wiart-Letort and S. Marion (UMR1080, Production du lait, INRA, Saint-Gilles, France) for their technical assistance. This research was financially supported by INRA.

\section{REFERENCES}

Accorsi, P. A., B. Pacioni, C. Pezzi, M. Forni, D. J. Flint, and E. Seren. 2002. Role of prolactin, growth hormone and insulin-like growth factor 1 in mammary gland involution in the dairy cow. J. Dairy Sci. 85:507-513.

Akers, R. M., D. E. Bauman, A. V. Capuco, G. T. Goodman, and H. A. Tucker. 1981a. Prolactin regulation of milk secretion and biochemical differentiation of mammary epithelial cells in periparturient cows. Endocrinology 109:23-30. 
Akers, R. M., D. E. Bauman, G. T. Goodman, A. V. Capuco, and H. A. Tucker. 1981b. Prolactin regulation of cytological differentiation of mammary epithelial cells in periparturient cows. Endocrinology 109:31-40.

Andersen, C. L., J. L. Jensen, and T. F. Ørntoft. 2004. Normalization of real-time quantitative reverse transcription-PCR data: A model-based variance estimation approach to identify genes suited for normalization, applied to bladder and colon cancer data sets. Cancer Res. 64:5245-5250.

Auchtung, T. L., A. G. Rius, P. E. Kendall, T. B. McFadden, and G. E. Dahl. 2005. Effects of photoperiod during the dry period on prolactin, prolactin receptor, and milk production of dairy cows. J. Dairy Sci. 88:121-127.

Baldi, A., S. Modina, F. Cheli, F. Gandolfi, L. Pinotti, L. B. Scesi, F. Fantuz, and V. Dell'Orto. 2002. Bovine somatotropin administration to dairy goats in late lactation: Effects on mammary gland function, composition and morphology. J. Dairy Sci. 85:10931102.

Ben Chedly, H., P. Lacasse, P.-G. Marnet, M. Komara, S. Marion, and M. Boutinaud. 2011. Use of milk epithelial cells to study regulation of cell activity and apoptosis during once-daily milking in goats. Animal 5:572-579.

Ben Chedly, H., P. Lacasse, P.-G. Marnet, S. Wiart-Letort, L. Finot, and M. Boutinaud. 2009. Cell junction disruption after 36h milk accumulation was associated with changes in mammary secretory tissue activity and dynamics in lactating dairy goats. J. Physiol. Pharmacol. 60(Suppl. 3):105-111.

Berlanga, J. J., J. P. Garcia-Ruiz, M. Perrot-Applanat, P. A. Kelly, and M. Edery. 1997. The short form of the prolactin (PRL) receptor silences PRL induction of the $\beta$-casein gene promoter. Mol. Endocrinol. 11:1449-1457.

Bernier-Dodier, P., L. Delbecchi, G. F. Wagner, B. G. Talbot, and P. Lacasse. 2010. Effect of milking frequency on lactation persistency and mammary gland remodeling in mid-lactation cows. J. Dairy Sci. 93:555-564.

Binart, N., A. Bachelot, and J. Bouilly. 2010. Impact of prolactin receptor isoforms on reproduction. Trends Endocrinol. Metab. $21: 362-368$

Boutinaud, M., M. H. Ben Chedly, E. Delamaire, and J. GuinardFlament. 2008. Milking and feed restriction regulate transcripts of mammary epithelial cells purified from milk. J. Dairy Sci 91:988-998.

Boutinaud, M., J. H. Shand, M. A. Park, K. Phillips, J. Beattie, D. J. Flint, and G. J. Allan. 2004. A quantitative RT-PCR study of the mRNA expression profile of the IGF axis during mammary gland development. J. Mol. Endocrinol. 33:195-207.

Buck, K., M. Vanek, B. Groner, and R. K. Ball. 1992. Multiple forms of prolactin receptor messenger ribonucleic acid are specifically expressed and regulated in murine tissues and the mammary cell line HC11. Endocrinology 130:1108-1114.

Capuco, A. V., S. E. Ellis, S. A. Hale, E. Long, R. A. Erdman, X. Zhao, and M. J. Paape. 2003. Lactation persistency: Insights from mammary cell proliferation studies. J. Anim. Sci. 81(Suppl. 3):18-31.

Choi, Y. J., W. L. Keller, I. E. Berg, C. S. Park, and A. G. Mackinlay. 1988. Casein gene expression in bovine mammary gland. J. Dairy Sci. $71: 2898-2903$

Colitti, M., G. Stradaioli, and B. Stefanon. 2005. Mammary cell turnover in lactating ewes is modulated by changes of energy fuels. Res. Vet. Sci. 78:53-59.

Das, R., and B. K. Vonderhaar. 1995. Transduction of prolactin's (PRL) growth signal through both long and short forms of the PRL receptor. Mol. Endocrinol. 9:1750-1759.

Farr, V. C., K. Stelwagen, L. R. Cate, A. J. Molenaar, T. B. McFadden, and S. R. Davis. 1996. An improved method for the routine biopsy of bovine mammary tissue. J. Dairy Sci. 79:543-549.
Fawcett, H. A. C., S. A. Baldwin, and D. J. Flint. 1992. Hormonal regulation of the glucose transporter GLUT I in the lactating rat mammary gland. Biochem. Soc. Trans. 20:17S

Kim, J. Y., Y. Mizoguchi, H. Yamaguchi, J. Enami, and S. Sakai. 1997. Removal of milk by suckling acutely increases the prolactin receptor gene expression in the lactating mouse mammary gland. Mol. Cell. Endocrinol. 131:31-38.

Knight, C. H. 2000. Overview of prolactin's role in farm animal lactation. Livest. Prod. Sci. 70:87-93.

Knight, C. H., M. Peaker, and C. J. Wilde. 1998. Local control of mammary development and function. Rev. Reprod. 3:104-112.

Knight, C. H., and C. J. Wilde. 1987. Mammary growth during lactation: Implications for increasing milk yield. J. Dairy Sci. 70:19912000.

Lacasse, P., V. Lollivier, R. M. Bruckmaier, Y. R. Boisclair, G. F. Wagner, and M. Boutinaud. 2011. Effect of the prolactin-release inhibitor quinagolide on lactating dairy cows. J. Dairy Sci. 94:1302-1309.

Lesueur, L., M. Edery, S. Ali, J. Paly, P. A. Kelly, and J. Djiane. 1991. Comparison of long and short forms of the prolactin receptor on prolactin-induced milk protein gene transcription. Proc. Natl. Acad. Sci. USA 88:824-828.

Littlejohn, M. D., C. G. Walker, H. E. Ward, K. B. Lehnert, R. G. Snell, G. A. Verkerk, R. J. Spelman, D. A. Clark, and S. R. Davis. 2010. Effects of reduced frequency of milk removal on gene expression in the bovine mammary gland. Physiol. Genomics 41:21-32.

Olazabal, I. J. Muñoz, S. Ogueta, E. Obregón, and J. P. GarcíaRuiz. 2000. Prolactin (PRL)-PRL receptor system increases cell proliferation involving JNK (c-Jun amino terminal kinase) and AP-1 activation: Inhibition by glucocorticoids. Mol. Endocrinol. 14:564-575.

Perrot-Applanat, M., O. Gualillo, A. Pezet, V. Vincent, M. Edery, and P. A. Kelly. 1997. Dominant negative and cooperative effects of mutant forms of prolactin receptor. Mol. Endocrinol. 11:1020 1032 .

Pfaffl, M. W., A. Tichopad, C. Prgomet, and T. P. Neuvians. 2004. Determination of stable housekeeping genes, differentially regulated target genes and sample integrity: BestKeeper-Excel-based tool using pair-wise correlations. Biotechnol. Lett. 26:509-515.

Plaut, K., D. E. Bauman, N. Agergaard, and R. M. Akers. 1987. Effect of exogenous prolactin administration on lactational performance of dairy cows. Domest. Anim. Endocrinol. 4:279-290.

Skarda, J., E. Urbanova, L.-M. Houdebine, C. Delouis, and J. Bilek. 1982. Effects of insulin, cortisol and prolactin on lipid, protein and casein syntheses in goat mammary tissue in organ culture. Reprod. Nutr. Dev. 22:379-386.

Taylor, J. C., and M. Peaker. 1975. Effects of bromocriptine on milk secretion in the rabbit. J. Endocrinol. 67:313-314.

Travers, M. T., M. C. Barber, E. Tonner, L. Quarrie, C. J. Wilde, and D. J. Flint. 1996. The role of prolactin and growth hormone in the regulation of casein gene expression and mammary cell survival: Relationships to milk synthesis and secretion. Endocrinology 137:1530-1539.

Wall, E. H., H. M. Crawford, S. E. Ellis, G. E. Dahl, and T. B. McFadden. 2006. Mammary response to exogenous prolactin or frequent milking during early lactation in dairy cows. J. Dairy Sci. 89:4640-4648.

Yu, C. C., and M. I. Filipe. 1993. Update on proliferation-associated antibodies applicable to formalin-fixed paraffin-embedded tissue and their clinical applications. Histochem. J. 25:843-853. 